\title{
ANNUAL REPORT OF THE CHIEF MEDICAL OFFICER OF THE MINISTRY OF HEALTH FOR THE YEAR I936
}

\section{Section on Venereal Diseases}

The experience of the year under report has continued to support the view that medical officers of health are increasingly zealous in their efforts to improve the measures of the County Councils and County Borough Councils for preventing the spread of venereal diseases.

\section{Treatment Centres}

The number of treatment centres in England and Wales at the close of I936 was I86 (including II9 conducted in voluntary hospitals). A new centre was opened at the Health Department, Tynemouth, for the treatment of women and children who had previously been dealt with at the Preston Hospital ; the latter centre now deals only with men. The centre at Newport, Isle of Wight, was moved to temporary premises pending rebuilding of the County Hall at which the centre had previously been conducted.

In the case of eight existing centres, new premises are either being erected or proposals are under discussion with officers of the Ministry. In one of these the locality of the centre is being moved from the voluntary hospital to the grounds of the municipal hospital, and when ready its administration will be in the hands of the local authority. Alterations of two existing centres and the erection of new centres in four towns at which facilities have not hitherto been provided were discussed. In the experience of the Department a reorganisation of any centre with provision of premises specially designed for the work has invariably been followed by a great increase in its turnover of cases even when the new centre has not had the cover of a general hospital.

The Incidence of Venereal Disease in England AND WALES

Syphilis.-In previous Reports it has frequently been stated that the annual returns of the centres afford reliable 


\section{VENEREAL DISEASES SCHEMES}

evidence of the incidence of syphilis in this country, the term " incidence" being intended to mean occurrence of fresh infections. The view that the centres dealt with the overwhelming majority of the early cases of syphilis occurring in the country was based on the results of enquiries amongst private practitioners and medical officers of health, the low proportion of Wassermann tests (approximately only one-twelfth of the total) carried out under the scheme for private practitioners and the slight evidence of any resort to unqualified persons for treatment.

$A$ priori it could reasonably be expected that comparatively few of those infected with syphilis would be treated privately because the great majority of the wage-earners are insured under the National Health Insurance scheme and it is in the interest of practitioners working under this scheme to refer their syphilitic patients to the centres. In order, however, to investigate the matter more closely enquiries have been made to determine the proportions of the total number of doses of arsenobenzene compounds sold in the country that were used in 1936 by the venereal diseases treatment centres, by institutions other than treatment centres and by private practitioners respectively. The information was obtained from three sources, namely: (a) The returns from the treatment centres; (b) medical officers of health of the counties and county. boroughs, who kindly supplied information respecting the numbers of doses of approved arsenobenzene compounds issued free, under the venereal diseases scheme, to practitioners and to institutions other than treatment centres ; (c) the makers and the agents for sale of these compounds, who were good enough to report the proportions of their total sales for use by private practitioners. The results showed that the total number of doses supplied under the scheme in England was approximately 295,750, of which the percentage used by centres, other institutions and private practitioners respectively were :-

$\begin{array}{llllll}\text { Venereal diseases treatment centres } & . & 88 \cdot 3 \\ \text { Institutions other than venereal diseases } & \\ \text { treatment centres } & . & . & . & . & 6 \cdot 8 \\ \text { Private practitioners } & . & . & . & . & 4.8\end{array}$

As regards the doses purchased outside the venereal diseases scheme, although only information respecting 


\section{BRITISH JOURNAL OF VENEREAL DISEASES}

percentages of the total sales was available, from knowledge of the extent to which the different brands are used it seems reasonable to estimate them at less than 5 per cent. of the total.

A number of medical officers of health added to their replies remarks which supported the view already held that in most of the syphilis cases treated in institutions other than treatment centres the infections were of old standing, the early cases being almost invariably referred to the treatment centres. Further, we know that many of the cases treated in institutions other than venereal diseases treatment centres and by private practitioners have at some time or other been under the care of the treatment centres, and have therefore been included in their returns, so that altogether it may be reckoned that the figures shown in the returns from the approved treatment centres probably account for more than 85 per cent. of the total number of the fresh infections in the country. These returns showed that in the year I936 the number of cases of syphilis with infections of less than one year's duration dealt with there for the first time was 5,675 , a reduction of 296 since the previous year and of 37.6 per cent. since I93I. Assuming that the calculations detailed above as to the cases not dealt with by the treatment centres are approximately correct, it would appear that the number of fresh infections dealt with by all centres, by other institutions and by private practitioners in the country in I936 did not exceed 6,500 or 7,000 cases, which represent a rate of less than $I \cdot 7$ per I0,000 of the population.

How much of the syphilis occurring in the country goes undetected cannot of course be stated. Certain American writers who have studied the question of ignored syphilis carefully have stated their belief that over 50 per cent. of the cases of syphilis occurring in the United States of America have not sought treatment until after the first year. It is difficult to believe that such a high proportion of cases of syphilis go so long undetected in this country, so far, at any rate, as males are concerned. Against such a supposition is the readiness with which persons who are suspicious that they have contracted a venereal disease resort to the treatment centres, as is shown in the steadily increasing numbers in Table A, Appendix F, under the heading "Other than Venereal Disease." 
In the case of males, further evidence of the tendency to seek advice early is the fact that the ratio of primary to secondary cases of syphilis dealt with for the first time in the five years I932 to I936 was I : 0.45. The ratios for England and Wales prior to I93I are not available, but in one large centre where careful records of the stage of syphilis on first attendance have always been kept, the ratio of primary to secondary syphilis in males improved from I : I.09 in I92I to I : 0.49 in I936. In each of the past six years the ratio at this centre has been approximately the same as that for the country, so that probably the improvement in earliness of reporting which it showed from I92I to I936 was fairly representative of what obtains in the country generally.

In prospective or actual mothers in England and Wales, as elsewhere, too much syphilis still passes undetected until the disease has been transmitted to infants. Fortunately, this gap is being closed by an increase in the practice of making routine tests of blood at ante-natal centres, with the permission of the patient. These routine tests give an indication of the prevalence of syphilis in married women in the places where they are conducted. In certain Reports for previous years reference has been made to the results of such blood tests at an ante-natal centre in Battersea in which the percentage of positive reactions fell from 3.5 in 1924, when the practice began, to 0.7 in 1936. At another centre in London at which routine tests were instituted last year 726 specimens gave 2.2 per cent. positive reactions; thanks to the tactful co-operation of a neighbouring treatment centre no trouble was experienced in securing the necessary treatment. In Cardiff routine tests of the women attending the ante-natal centres have been carried out since June, I925. According to the report of the Medical Officer of Health for 1935, from 1925 to the end of 1928 the percentage with positive reactions was $3 \cdot I$. By the end of I934 the number of tests from the commencement was 7,935 and the percentage found positive was $2 \cdot 2$. In I935 the number of tests was I,253 of which I. 8 per cent. gave positive results. To these figures may be added some obtained in Glasgow. Here, according to an article by Dr. Nora Wattie (The Medical Officer, I937, 5\%, I6), routine testing at ante-natal clinics was instituted in 1925 when the results of $93^{8}$ tests showed 4.9 per cent. to be 


\section{BRITISH JOURNAL OF VENEREAL DISEASES}

positive. By the end of 1935 the number tested annually had increased to $8,5 \mathrm{I} 4$ and the percentage of positive reactions was $\mathrm{I} \cdot 8$.

As a contrast to the figures given above may be mentioned some obtained in earlier years. In I,88I unselected mothers investigated by J. N. Cruickshank (Medical Research Council, Special Report Series No. 82) at the Glasgow Royal Maternity and Women's Hospital in I920-I the percentage which gave positive serum reactions was $9 \cdot 04(8 \cdot 9 I$ per cent. in the married and II. I6 per cent. in the unmarried).

In the memorandum presented by Fildes to the Royal Commission on Venereal Diseases it was shown that of 6I6 adult males who attended the London Hospital " for reasons wholly unconnected with syphilis" Io.3 per cent. gave positive Wassermann reactions, and of 386 adult women tested in the same circumstances $5 \cdot I$ per cent. were positive. The great majority of the persons providing these results had attended the hospital as a result of accidents, and none appears to have had a medical condition remotely related to syphilis. The figures are too few in numbers to justify a general conclusion, but to some extent they may be representative of the prevalence of syphilis in the working-class population of East London in I9I4.

Deaths of infants certified as due to syphilis were at the rate of 0.27 per I,000 live births, as shown in Table F. The figures with those in Table $\mathrm{E}$ are evidence of a substantial reduction in the transmission of syphilis to the second generation.

The facts stated above seem to show that the measures taken under the Venereal Diseases Regulations are lowering the incidence of fresh infections with syphilis in this country, and lessening the transmission of the disease to the next generation. As mentioned, however, there is evidence that too much syphilis in women and girls still goes undetected. Much could be done to remedy this defect. Routine tests of the blood of pregnant women attending ante-natal centres with the patient's permission have been mentioned. Besides this an extension of the practice obtaining in a number of clinics of testing the blood of every patient whether syphilis is suspected or not may reveal latent syphilis in women.

Deaths from general paralysis of the insane again showed 


\section{VENEREAL DISEASES SCHEMES}

a decrease, the figures in 1936 being males 652 , females 232, and the crude rates per million living 33 and II. The corresponding rates in I9II were IOI and 23 , and in I920 they were $7 \mathrm{I}$ and $\mathrm{I} 2$. The slightness of the reduction in the female death rates since I920 contrasts strongly with that of the male, and shows again that more ought to be done to search out and treat syphilis in women.

Deaths from tabes showed a decease to 496 in males and to I04 in females. The crude rate was 25 in males; it contrasts with 30 in I9II, and 29 in I920. In females the rate was 5 ; it compares with 6 in I9II, and 4 in I920. It appears therefore that although there has been some decrease in the case of males, the rate in females has remained practically stationary.

Gonorrhoea.-The cases dealt with for the first time in I936 are shown in Appendix F, Table C. Of the 28, I37 male cases and the 7,7I5 female cases, 26,502 males and 6,640 females, total 33,142 , had infections of less than one year's duration. The 33,I42 cases represent a rate of $8 \cdot \mathrm{I}$ per I0,000 of the population of England and Wales (males 13.6 and females $3 \cdot 1$ per I0,000 of the male and female populations respectively). The rate of $8 \cdot \mathrm{I}$ was considerably lower than those of some other countries where campaigns against venereal disease have been pursued actively for many years. Thus in 1934, according to. official notifications, the rate in Sweden was 18.6 and in Denmark 27.2. The differences suggest that the centres in this country are not yet attracting a sufficient proportion of the members of the community infected with gonorrhœa. It follows that increases in the numbers of gonorrhœa cases dealt with by the centres do not necessarily mean increases in the incidence of the disease.

In the case of females especially there are strong grounds for believing that the centres deal with only a fraction of the cases occurring in the community. Thus in fresh infections with syphlis the ratio of females to males in 1936 was $I: 2 \cdot 4$, while in fresh infections with gonorrhœa it was I : 4 . There is no evidence of large numbers of cases of gonorrhœa in women being treated by private practitioners or of women being more resistant to the gonococcus than to $S$. pallida, so that the difference between the two ratios leads to the inevitable conclusion that a large amount of gonorrhœa in women 


\section{BRITISH JOURNAL OF VENEREAL DISEASES}

must be going untreated. One reason to which attention has been drawn repeatedly in previous Annual Reports is that the symptoms of gonorrhœa in women are often very slight and are attributed to simple causes which can be dealt with by home remedies. Whatever the cause, this frequent neglect by women with gonorrhœa to seek treatment, together with the suspicion that a certain amount of syphilis in the same sex is overlooked, points to the need of improvement in measures to enlighten the public on the subject of venereal disease.

Soft Chancre.- The figures relating to soft chancre are of only slight importance. The high ratio of males to females, $880: 29$, is noteworthy, as is also the fact that most of the cases were reported by centres in ports. There is no evidence of any notable increase in cases of lymphogranuloma inguinale or of disabilities resulting from infection with the same virus.

Failure to Seek Skilled Advice for Venereal Disease and Premature Discontinuance of AttendANCE AT THE CENTRES

The reduction in the incidence of venereal diseases depends partly on the success of the measures taken under the venereal diseases scheme to dissuade people from extra-marital sexual intercourse, and to render the greatest possible percentage of the infected in the community non-infectious; this in turn depends partly on the proportion that are brought under treatment and partly on the perseverance with treatment until no longer contagious. The proportion dissuaded from extramarital intercourse depends chiefly on enlightenment of the public. The proportion of the infected brought under treatment depends not only on enlightenment of the public but on the tracing of contacts and on the collaboration of the Venereal Diseases Service with others, such as the Maternity and Child Welfare and the School Medical Services, which are in a position to detect syphilis and gonorrhœa in the women and children whom they have to examine in the ordinary course of their work. Perseverance with treatment, besides being dependent on enlightenment of the public, is affected by certain other factors and merits special discussion here because of its great importance. 


\section{VENEREAL DISEASES SCHEMES}

The percentages of patients on the books of the treatment centres who discontinued attendance before being discharged as cured during the ten years ending 3Ist December, I936, were as follows :-

\begin{tabular}{|c|c|c|c|c|c|c|c|}
\hline & & & & \multicolumn{2}{|c|}{ Syphilis. } & \multicolumn{2}{|c|}{ Gonorrhœa. } \\
\hline & & & & Males. & Females. & Males. & Females. \\
\hline I927 & . & - & - & $24 \cdot 4$ & $2 I \cdot 5$ & $30 \cdot 4$ & $20 \cdot 0$ \\
\hline I930 & . & - & - & $22 \cdot 9$ & $22 \cdot 6$ & $27 \cdot 9$ & $22 \cdot 7$ \\
\hline I933 & . & - & . & $20 \cdot 5$ & $22 \cdot 2$ & $26 \cdot 4$ & $24 \cdot 3$ \\
\hline I936 & . & . & . & $I 9 \cdot I$ & $I 8 \cdot I$ & $23 \cdot 2$ & $I 8 \cdot 4$ \\
\hline
\end{tabular}

Of the cases constituting the above percentages, in syphilis from a quarter to a sixth and in gonorrhœa from a third to a quarter had completed the prescribed treatment and were under tests for cure at the time they ceased attendance. The figures depend on varying criteria of sufficiency of treatment which are observed by the different medical officers. Thus of two syphilitic patients attending two centres who ceased attendance after receiving fourteen months of identical treatment, one might be classed as having ceased attendance before completion of treatment and the other as having ceased attendance after completion of treatment but before final tests of cure. In other words, although both had received the same amount of treatment one would be classed in a worse category and might be regarded by some as a greater danger than the other. It should also be noted that a syphilitic patient who ceases attendance is not necessarily contagious or likely to become so. Of the patients with early syphilis who ceased attendance prematurely in I936, approximately 70 per cent. of the males and 72 per cent. of the females had received more than one course of injections, and it is probable that a high proportion of them had been made permanently non-contagious by the time they discontinued attendance. In spite, however, of these mitigating factors it cannot be denied that there is too much premature discontinuance of attendance by syphilitic patients and especially so by those who are child-bearing women.

In gonorrhœa, although the figures are also subject to the varying standards by which medical officers are guided in determining whether or not a patient has been cured, they demand serious effort to bring about their reduction.

The remedies for the defects discussed above-relative 


\section{BRITISH JOURNAL OF VENEREAL DISEASES}

failure of women with gonorrhœa or syphilis to seek treatment and premature discontinuance of attendance by both sexes-seem to fall under two main headings: (a) legislation designed to compel the infected to undergo treatment, and $(b)$ improvements in existing methods of persuasion.

Treatment of Syphilis.-The report and recommendations of the Committee of Experts convened by the Health Organisation of the League of Nations on the treatment of early syphilis were sent to the medical officers of health of the counties and county boroughs for the information of the venereal diseases officers working in their areas, with the following covering letter :-

DEAR SIR,

$$
\text { 3Ist July, I936. }
$$

\section{Treatment of Venereal Diseases}

In connection with the Council's scheme for the treatment of venereal diseases, I am desired to forward to you the accompanying reprint of the Report published in March, I935, by the Health Organisation of the League of Nations on the treatment of syphilis, and to request that you will be good enough to transmit the Report for the information of the Medical Officer-in-charge of each Treatment Centre in your area, which is approved by the Minister under the Public Health (Venereal Diseases) Regulations, I9I6. Any further copies of the Report which may be required for the purpose can be purchased from Messrs. George Allen and Unwin, Ltd. (League of Nations Department), 40, Museum Street, London, W.C.I, price $2 s$. each.

As will be seen the Report embodies the recommendations of a Committee of Experts following an exhaustive enquiry into the results of syphilis treatment in five countries ; it will no doubt be of interest to every Medical Officer who is engaged in the venereal diseases service of this country.

Yours faithfully,

(Sgd.) Arthur S. MacNalty, Chief Medical Officer. 
The Testing of New Remedies.-The Sub-Committee of the Therapeutic Trials Committee of the Medical Research Council which was mentioned in last year's Report as having been formed for the purpose of testing new remedies for venereal diseases continued its investigations of certain remedies for syphilis without being able to conclude that any was of outstanding merit.

\section{Laboratory Assistance in the Diagnosis of Venereal Disease}

In Table $G$ are shown the numbers of pathological specimens examined under the venereal diseases scheme in the approved laboratories and the treatment centres. The total of 735,554 was an increase of 23,148 over the number in 1935 .

In 1936 for the first time the returns from the approved laboratories distinguished between tests for practitioners and those for institutions other than treatment centres. The figures showed that approximately 9 per cent. of the Wassermann tests, $\mathrm{I} \cdot 57$ per cent. of the microscopical tests for $S$. pallida and $3 \cdot 8$ per cent. of the microscopical tests (other than cultural) for gonococci related to specimens from patients of private practitioners. The very low percentage of the specimens for detection of S. pallida that were sent by private practitioners and by institutions other than treatment centres tends to support what has been stated above to the effect that the overwhelming majority of the patients with early syphilis who seek the advice of qualified practitioners in this country are dealt with at the treatment centres.

Serum tests for syphilis increased by 22,438 , the increase being made up of 6,868 Wassermann and 15,570 flocculation tests. The flocculation tests were usually supplementary to the Wassermann, and the figures indicate that now approximately 30 per cent. of the serum specimens are tested by two or more methods (generally two). The practice of testing sera for syphilis by at least two methods, which has been recommended by the Health Organisation of the League of Nations, appears to be increasing since in I932 it was applied to only about 20 per cent. of the specimens sent for syphilitic serum tests. It is still, however, not so general as could be desired, or as obtains in the more progressive European countries, and it is a matter for some regret that the relatively high

v.D. 


\section{BRITISH JOURNAL OF VENEREAL DISEASES}

fees charged by a number of laboratories for serum tests is interfering with progress in this respect. Tests of the cerebrospinal fluid again showed an increase, but the figures indicate that the practice is still by no means so prevalent as could be desired in the interests of the prevention of late neuro-syphilis.

In gonorrhoe $a$ there was again an increase in the number of cultures, which, at 70,228, were approximately 6 per cent. more than in I935 and nearly three times as many as in I932. The treatment centres provided 98 per cent. of the specimens. Serum tests for gonorrhœa, at 5I,036, were more than double the number performed in I932, and the number of laboratories in which these tests were carried out increased from 44 to 54 . Six or seven years ago only four or five of the approved laboratories in this country would undertake this test. The increases in cultures and gonococcal complement fixation tests, both of them particularly valuable in the diagnosis of gonorrhœa in the female and in tests of cure in both sexes, are indications of steady improvement in the efficiency of the treatment centres.

The comparisons of the different methods of the Wassermann test employed in approved laboratories with No. I Method of the Medical Research Council as modified by Wyler (Medical Research Council, Special Report Series No. 129) was continued and by the end of I936, I3 8 had been completed. As mentioned in previous Reports, the opportunities which these comparisons afford pathologists of reviewing their methods have been welcomed and have led to considerable improvement in the reliability of syphilitic serum tests in this country.

\section{CONFERENCES}

Col. L. W. Harrison, a medical officer of the Ministry of Health, attended the General Assembly of the Union Internationale contre le Péril Vénérien at Amsterdam in July, I936, when the following items were discussed : The campaign against venereal diseases in Holland, and the international problem presented by venereal diseases in boatmen on the Rhine.

Colonel Harrison attended also the International Labour Conference at Geneva in October, I936, as a technical adviser in the discussion on "Promotion of Seamen's Welfare in Ports." 


\section{VENEREAL DISEASES SCHEMES}

\section{APPENDIX F}

\section{England and Wales: Tables relating to Venereal Diseases}

\section{TABLE A}

\begin{tabular}{|c|c|c|c|c|c|c|c|c|}
\hline \multirow{2}{*}{ Year } & \multicolumn{6}{|c|}{$\begin{array}{l}\text { Number of cases dealt with for the first time at the } \\
\text { Treatment Centres* }\end{array}$} & \multirow{2}{*}{$\begin{array}{c}\text { Total } \\
\text { number of } \\
\text { attendances }\end{array}$} & \multirow{2}{*}{$\begin{array}{c}\text { Number of } \\
\text { Treatment } \\
\text { Centres at } \\
\text { end of } \\
\text { year }\end{array}$} \\
\hline & Syphilis & $\begin{array}{c}\text { Soft } \\
\text { chancre }\end{array}$ & Gonorrhœa & $\begin{array}{l}\text { Total } \\
\text { V.D. }\end{array}$ & $\begin{array}{l}\text { Other } \\
\text { than } \\
\text { V.D. }\end{array}$ & Total & & \\
\hline I9I 7 & - & - & 一 & - & - & 29,036 & 204,692 & I I 3 \\
\hline 1918 & 26,912 & 806 & I 7,635 & 45,353 & 6,622 & $5 \mathrm{I}, 975$ & 488, I 37 & I 34 \\
\hline 1919 & 42, I 34 & 2,164 & $3^{8,499}$ & 82,797 & I 5,447 & 98,244 & $\mathrm{I}, 002,791$ & 160 \\
\hline 1920 & 42,805 & 2,442 & 40,284 & $85,53 \mathrm{I}$ & I9,654 & 105,185 & $\mathrm{I}, 488,5^{\mathrm{I}} 4$ & I90 \\
\hline I92 I & 32,733 & $\mathrm{I}, 654$ & 32,433 & 66,820 & I 7,459 & 84,279 & I,6I 2,592 & I94 \\
\hline I922 & 25,762 & $\mathrm{I}, \mathrm{IO} 8$ & 29,477 & 56,347 & I 6,988 & 73,335 & $I, 5^{60}, 5^{68}$ & I9I \\
\hline 1923 & 23,927 & I, I IO & 30,908 & 55,945 & I 7,668 & 73,613 & $\mathrm{I}, 60_{5}, 6 \mathrm{I} 7$ & I92 \\
\hline 1924 & 22,010 & 1,098 & 31,272 & 54,380 & I 8,842 & 73,222 & $\mathrm{I}, 645,4 \mathrm{I} 5$ & I93 \\
\hline I925 & 22,588 & I, 106 & 33,463 & 57, I 57 & $2 \mathrm{I}, 053$ & $78,2 \mathrm{IO}$ & $\mathrm{r}, 7 \mathrm{I} 9, \mathrm{r}_{4} 8$ & I93 \\
\hline 1926 & $22,55^{\circ}$ & $\mathrm{I}, \mathrm{I} 5^{\circ}$ & 35,052 & $5^{8,752}$ & 22,754 & 81,506 & $2,008,063$ & I90 \\
\hline I927 & 23,395 & 1,063 & 38,242 & 62,700 & $25,43^{6}$ & 88, I 36 & $2,179,707$ & I 86 \\
\hline 1928 & $22,76 \mathrm{I}$ & $I, I 38$ & 42,032 & $65,93 \mathrm{I}$ & 28,029 & 93,960 & $2,422,749$ & I 88 \\
\hline I929 & 22,019 & I, 298 & $44, I 66$ & 67,483 & 27,980 & 95,463 & $2,604,217$ & I 88 \\
\hline I930 & 23,120 & $I, 324$ & 45,001 & 69,445 & $3 \mathrm{I}, \mathrm{IO} 4$ & Ioo, 549 & $2,817,195$ & I90 \\
\hline I93I & 22,934 & $I, 163$ & 42,460 & 66,557 & $3 \mathrm{I}, 82 \mathrm{I}$ & 98,378 & $2,992,761$ & I 89 \\
\hline 1932 & 22,215 & 952 & $4^{I}, 25 I$ & 64,4 I 8 & 32,997 & $97,4 \times 5$ & 3, I O9, I 74 & I 88 \\
\hline I933 & 21,525 & 926 & 43,226 & 65,677 & 32,767 & 98,444 & $3,25^{2}, 323$ & I 86 \\
\hline I934 & 20,692 & 960 & $43,39 I$ & 65,043 & 36,3 I I & IOI, 354 & $3,407,000$ & I 84 \\
\hline I935 & I9, 335 & I , I I 2 & 41,332 & 61,779 & 36,230 & 98,009 & $3,398,678$ & I 85 \\
\hline 1936 & I 8,609 & $\mathrm{I}, \mathrm{OOO}$ & 42,230 & 61,839 & 36,7 I9 & $98,55^{8}$ & $3,360,328$ & I 86 \\
\hline
\end{tabular}

* Includes cases transferred from centre to centre and cases that returned after being struck off the books in previous years.

\section{TABlE B.-Attendances per Current Case}

\begin{tabular}{|c|c|c|c|c|}
\hline \multirow{2}{*}{ Year } & \multicolumn{2}{|c|}{ Syphilis } & \multicolumn{2}{|c|}{ Gonorrhœa } \\
\hline & Males & Females & Males & Females \\
\hline I923 & $6 \cdot 8$ & $7 \cdot 3$ & I $5 \cdot 7$ & I 5.5 \\
\hline 1928 & $9 \cdot I$ & $9 \cdot 3$ & $24^{\circ} 0$ & $18 \cdot I$ \\
\hline 1929 & $9 \cdot 5$ & $9 \cdot 2$ & $24^{\circ} 5$ & $17 \cdot 7$ \\
\hline $193^{\circ}$ & $9 \cdot 8$ & $9 \cdot 7$ & $26 \cdot 5$ & $18 \cdot 0$ \\
\hline I93I & $10 \cdot 7$ & I I $\cdot O$ & $29 \cdot 0$ & $20 \cdot 4$ \\
\hline 1932 & I I $\cdot 9$ & $\mathrm{I} 2 \cdot \mathrm{O}$ & $3^{I} \cdot 7$ & $2 \mathrm{I} \cdot 4$ \\
\hline I933 & $\mathrm{I} 2 \cdot 2$ & I $2 \cdot 5$ & $32 \cdot 2$ & $23 \cdot 5$ \\
\hline I934 & I $2 \cdot 4$ & I $3 \cdot$ I & $34^{\circ} \mathrm{O}$ & $25^{\circ} 9$ \\
\hline I935 & I $2 \cdot 9$ & 13.6 & $34^{\circ} 9$ & $26 \cdot 5$ \\
\hline I936 & I $2 \cdot 9$ & I 3.8 & $34 \cdot 3$ & $27 \cdot 4$ \\
\hline
\end{tabular}


BRITISH JOURNAL OF VENEREAL DISEASES

TABLE C.-Number of Cases dealt with for the first time at any Centre*

\begin{tabular}{|c|c|c|c|c|c|c|}
\hline \multicolumn{3}{|c|}{ Year } & Syphilis & Soft chancre & Gonorrhœea & Total V.D. \\
\hline 恿 & $\begin{array}{l}1925 \\
1926 \\
1927 \\
1928 \\
1929 \\
1930 \\
1931 \\
1932 \\
1933 \\
1934 \\
1935 \\
1936\end{array}$ & $\begin{array}{l}\cdot \\
\cdot \\
.\end{array}$ & $\begin{array}{l}\text { I I }, 782 \\
\text { I } 2, \text { I I } 8 \\
\text { I } 2,393 \\
\text { I } 2,051 \\
\text { I I,538 } \\
\text { I I,967 } \\
\text { I I,285 } \\
\text { I I, 032 } \\
\text { I0,738 } \\
9,615 \\
8,596 \\
8,224\end{array}$ & $\begin{array}{r}\mathrm{I}, 048 \\
\mathrm{I}, 070 \\
986 \\
\mathrm{I}, \mathrm{O} 53 \\
\mathrm{I}, 202 \\
\mathrm{I}, 244 \\
\mathrm{I}, 042 \\
845 \\
826 \\
876 \\
\mathrm{I}, \mathrm{OI} \mathrm{I} \\
880\end{array}$ & $\begin{array}{l}24,398 \\
25,535 \\
28,195 \\
30,425 \\
31,810 \\
32,217 \\
29,310 \\
28,179 \\
29,169 \\
28,787 \\
27,506 \\
28,137\end{array}$ & $\begin{array}{l}37,228 \\
38,723 \\
41,574 \\
43,529 \\
44,550 \\
45,428 \\
41,637 \\
40,056 \\
40,733 \\
39,278 \\
37,113 \\
37,241\end{array}$ \\
\hline 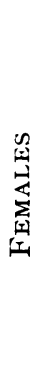 & $\begin{array}{l}1925 \\
1926 \\
1927 \\
1928 \\
1929 \\
1930 \\
1931 \\
1932 \\
1933 \\
1934 \\
1935 \\
1936\end{array}$ & 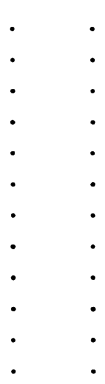 & $\begin{array}{l}7,385 \\
7,133 \\
7,553 \\
7,090 \\
6,586 \\
6,916 \\
6,827 \\
6,461 \\
6,029 \\
5,838 \\
5,565 \\
5.128\end{array}$ & $\begin{array}{l}27 \\
21 \\
20 \\
28 \\
22 \\
17 \\
20 \\
29 \\
22 \\
10 \\
16 \\
29\end{array}$ & $\begin{array}{l}6,120 \\
6,416 \\
6,809 \\
7,8 \text { I0 } \\
7,798 \\
7,939 \\
7,697 \\
7,677 \\
8,583 \\
8,199 \\
7,732 \\
7,715\end{array}$ & 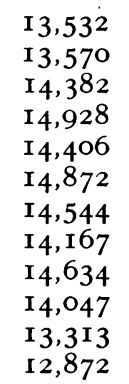 \\
\hline
\end{tabular}

* Excludes cases transferred from centre to centre and those that returned with the same infections after being struck off the books in previous years.

TABLE D.-Cases of Acquired Syphilis in Table C with Infections of less than One Year

\begin{tabular}{|c|c|c|c|c|c|c|c|}
\hline & \multirow{2}{*}{ Year } & & \multicolumn{2}{|c|}{ Number } & \multicolumn{2}{|c|}{ Per cent. of Table $C$ cases } & \multirow{2}{*}{$\begin{array}{l}\text { Rate per } \\
\text { Io,ooo } \\
\text { population }\end{array}$} \\
\hline & & & M. & F. & M. & F. & \\
\hline I93 I & - & - & $6,42 \mathrm{I}$ & 2,683 & $56 \cdot 9$ & $39 \cdot 3$ & $2 \cdot 28$ \\
\hline 1932 & - & • & 6,196 & 2,532 & $56 \cdot 2$ & $39 \cdot 2$ & $2 \cdot 17$ \\
\hline 1933 & • & $\cdot$ & 5,949 & $2,14 \mathrm{I}$ & $55^{\circ} 4$ & $35 \cdot 5$ & $2 \cdot O I$ \\
\hline I934 & - & - & 4,888 & 2,030 & $50 \cdot 8$ & $34 \cdot 8$ & $I \cdot 7 I$ \\
\hline I935 & - & - & 4,226 & $\mathrm{I}, 745$ & $49 \cdot 2$ & $3 I \cdot 4$ & $\mathrm{I} \cdot 47$ \\
\hline 1936 & - & - & 4,033 & 1,642 & $49 \cdot 0$ & $32 \cdot 0$ & $I \cdot 40$ \\
\hline
\end{tabular}

更

(ִ

穴

है 


\section{VENEREAL DISEASES SCHEMES}

TABLE E.-Cases of Congenital Syphilis dealt with for the first time at the Treatment Centres

\begin{tabular}{|c|c|c|c|c|c|}
\hline Year & $\begin{array}{l}\text { Under } \\
\text { I year }\end{array}$ & $\begin{array}{l}\text { I and under } \\
5 \text { years }\end{array}$ & $\begin{array}{l}5 \text { and under } \\
\text { 15 years }\end{array}$ & $\begin{array}{l}\text { I5 years and } \\
\text { over }\end{array}$ & Totals \\
\hline I93I & 339 & 204 & $974^{\circ}$ & 922 & 2,439 \\
\hline I932 & 302 & I 80 & 857 & 805 & $2, \mathrm{I} 44$ \\
\hline I933 & 305 & I 57 & 774 & 780 & 2,016 \\
\hline I934 & 296 & 165 & 708 & 839 & 2,008 \\
\hline I935 & $25 \mathrm{I}$ & 165 & 671 & 944 & $2,03 \mathrm{I}$ \\
\hline 1936 & $24 I$ & I 32 & 600 & 935 & $\mathbf{I}, 908$ \\
\hline
\end{tabular}

TABLE F.-Death Rates, per I, ooo Live Births, of Infants under One Year certified as due to Syphilis.-Information extracted from the Registrar-General's Statistical Reviews

\begin{tabular}{|c|c|c|c|c|c|c|c|c|c|c|}
\hline I9I 2 & - & - & - & . & $I \cdot 34$ & I925 & - & - & . & 0.82 \\
\hline I9I3 & - & . & - & . & $I \cdot 4^{6}$ & I926 & - & . & . & 0.84 \\
\hline 1914 & . & . & . & . & $I \cdot 55$ & I927 & . & . & . & 0.77 \\
\hline I9I 5 & . & . & . & . & $I \cdot 44$ & 1928 & . & . & . & $0.7 \mathrm{I}$ \\
\hline 1916 & . & . & . & . & $\mathbf{I} \cdot 57$ & I929 & . & . & . & 0.64 \\
\hline I9I 7 & . & . & . & . & 2.03 & I930 & . & . & . & 0.55 \\
\hline 1918 & . & . & . & . & $I \cdot 90$ & I93I & . & . & . & $0.5 \mathrm{I}$ \\
\hline 1919 & . & . & . & . & $I \cdot 76$ & $193^{2}$ & . & . & . & 0.47 \\
\hline 1920 & . & . & . & . & $I \cdot 5^{I}$ & I933 & . & . & . & 0.40 \\
\hline 1921 & . & . & . & . & $I \cdot 43$ & I934 & . & . & . & 0.34 \\
\hline 1922 & . & . & . & . & $\mathrm{I} \cdot \mathrm{I} 2$ & I935 & . & . & . & 0.29 \\
\hline I923 & . & . & . & . & $\mathrm{I} \cdot \mathrm{O}_{5}$ & 1936 & . & . & . & 0.27 \\
\hline I924 & . & . & . & • & $0.9 \mathrm{I}$ & & & & & \\
\hline
\end{tabular}

